\title{
Assessment of NEWMAP Effects on Gully Erosion Control and Environmental Development over South East, Nigeria
}

\author{
Oyati E. N., Lawal A.F., Ojo O.J.
}

\begin{abstract}
The potential impacts of gully erosion over South Eastern Nigeria are a worrisome scenario. It has resulted in the displacement of millions of habitats, agricultural, and economic losses. The result of the effect of Nigerian Erosion Watershed Management Project (NEWMAP) monitoring and evaluation on the effect of gully erosion on economic development in this study has revealed a positive significant influence at $P<0.05$ over the study region. Also, it is revealed that NEWMAP programmes have significantly covered some constructions of hydraulic structures for flood routing and soil erosion control in South East, Nigeria. This intervention has significantly reduced the rate of land degradation occasioned by soil erosion, protection of watershed and agricultural land, which has thus been responsible for improved agricultural production. In conclusion, it is imperative to conduct periodic monitoring and evaluation of the activities of NEWMAP to building a strong evidence-based mechanism that enhances assessment of the diverse range of intervention projects on the dwellers of South-East extraction.
\end{abstract}

Keywords: NEWMAP, Gully-erosion, South-East, Land degradation, Soil erosion

\section{INTRODUCTION}

Generally, soil erosion is a serious form of land degradation. This devastating process could be caused through air or water. It is a major challenge in Nigeria particularly in States like Yobe State and the States in South-East, Nigeria. The effect of gully erosion in the south-eastern Nigeria is fast becoming hazardous for human habitation as hundreds of people are directly affected every year and have to be relocated (Ezezika \& Adetona, 2011; Henry et al., 2014). The period between 1920 and the present has witnessed not only the disappearance of arable lands but also numerous loses of lives and properties due to gully erosion. Large areas of agricultural lands are becoming unsuitable for cultivation as erosion destroys farmlands and

Manuscript received on 12 October 2021 | Revised Manuscript received on 28 October 2021 | Manuscript Accepted on 15 November 2021 | Manuscript published on 30 November 2021. * Correspondence Author

Oyati E.N*, Department of Project Management Technology, The Federal University of Technology, Akure, Nigeria. Email: edithoyati@gmail.com

Lawal A.F., Department of Project Management Technology, The Federal University of Technology, Akure, Nigeria. Email: aflawa@futa.edu.ng

Ojo O.J, Department of Project Management Technology, The Federal University of Technology, Akure, Nigeria. Email: ojojo@futa.edu.ng

(C) The Authors. Published by Lattice Science Publication (LSP). This is an open access article under the CC-BY-NC-ND license (http://creativecommons.org/licenses/by-nc-nd/4.0/) lowers agricultural productivity (Egboka, Nwakwor \& Orajaka, 1990). More than 1000 farmland sites were washed, thereby denying the people one of their main source of livelihood (Ujumadu et al., 2016).

Also, aquatic life has seriously been affected because the eroded soil has been transported to the river and as thus fill the reserviour storage area, displaces the aquatic life and reduces the reserviour capacity of river. Consequently, this has been fingered as a major problem of economic depression for a teeming population whose their lives depend on these aquatic lives as fishermen. Also, shortage of water for municipal supply would also be affected. It has been concluded that if this trend continues without abated and managed adequately, it may lead to irreversible socio-economic damage and loss over the South-East, Nigeria.

The economic damage brought by gullies, mainly in Nigeria's southeast could be up to $\$ 100$ million every year, with an agricultural yield loss of $30-90 \%$ in some areas (Climate Home News, 2020). Gully erosion contributes to environmental problems and cause damage estimated at over $\$ 100$ million annually in most parts of Nigeria (NEWMAP, 2018). This is a threat to the Federal Government of Nigeria's "Vision 202020" as it undermines the sustainable growth of the affected communities (NEWMAP, 2018).

Even though there are no empirical researches on NEWMAP and sustainable development of Southeast, Nigeria. Similar studies on the impacts of sustainable development have assessed effects using several group indicators that encompass the most relevant areas of any sustainable development strategy: social, economic and environmental. Some common indicators used to evaluate the economic aspects of sustainable development achievements of development projects are households' and/or per capita income (Subbarao and Lloyd, 2011); Bayer, as well as generation of local employment and technology transfer (Schneider, Holzer, \& Hoffmann, 2008). Some sites gully erosion are depicted in plate 1-3.

Therefore, the study is focused to investigate the effect of NEWMAP on environmental development of South-east, Nigeria towards the formation of a solid and sustainable environmental system.

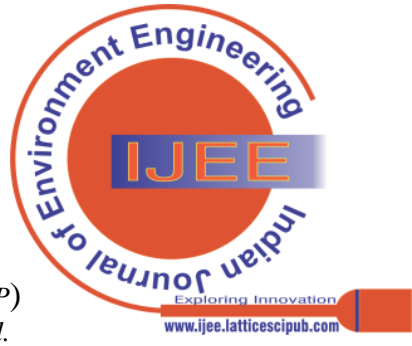



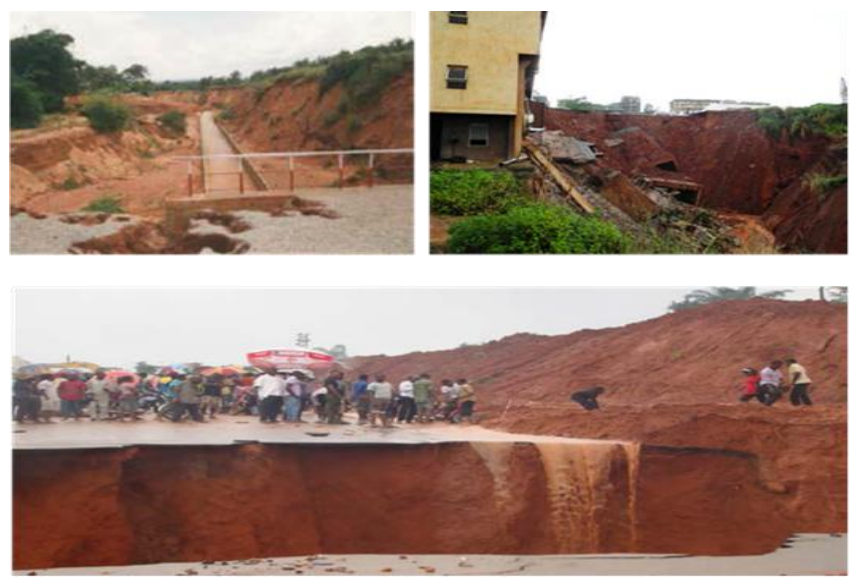

Plate 1: Some of gully erosion devastating sites (Erosion site at Awka in Anambra State)

Source: Field study, 2020

\section{METHODOLOGY}

\section{A. Study area}

The study area is dominated by two major seasons: rainy season and dry season. Rainy season ranges from March to October with its peak in July and September, and a short break in August. The dry season ranges from November to February with the influence of harmattan felt between the months of December and January. These seasonal changes with its attendant changes in temperature, runoff, humidity, atmospheric and pore pressure contribute to the disintegration and washing away of the soil and rock units in the study area. The vegetation in the area is controlled by geologic factors of topography, relief and lithology as well as other anthropogenic factors. The vegetation ranges from light rainforest to savannah. Dense vegetal cover with high trees is prominent around stream and the shaley lowlands while savannah vegetation and isolated trees are prominent on sandy highland. The area supports extensive man-made vegetation community which comprises mainly cashew orchard and palm trees. Human activities such as bush burning, agriculture and construction works have greatly modified the natural vegetation in the area and contributed to the gully erosion problem that is prominent.

The geological setting in the study area is that of layered sequences in which a predominantly sandstone formation is underlain by a predominantly shale formation (Ezechi \& Okagbue, 1989). The Imo Shale (Palaeocene - Lower Eocene) is a transgressive sequence of dark grey shale and outcrops on the plane of the Mamu River. No active gullies are found in this formation. The Ameki Formation (Middle sandstone units with intercalations of claystone, shale and limestone. The sandstone is expressed as a NW - SE trending cuesta with a north-east facing scarp slope. Active gullies of enormous magnitude are found in this unit (Ezechi \& Okagbue, 1989). The general strike of the rock unit is approximately $\mathrm{N}-\mathrm{S}$ with a gentle westward dip of less than $5^{0}$. The soils of the study area are derived from the underlying Ameki Formation and Imo Shale and as such comprise mainly porous, red and brown sandy soils, and brown and pale clay soils. Fig. 1 shows the position of the study area. Fig. 2 shows the conceptual framework of the study. Upper Eocene) is a regressive sequence composed of

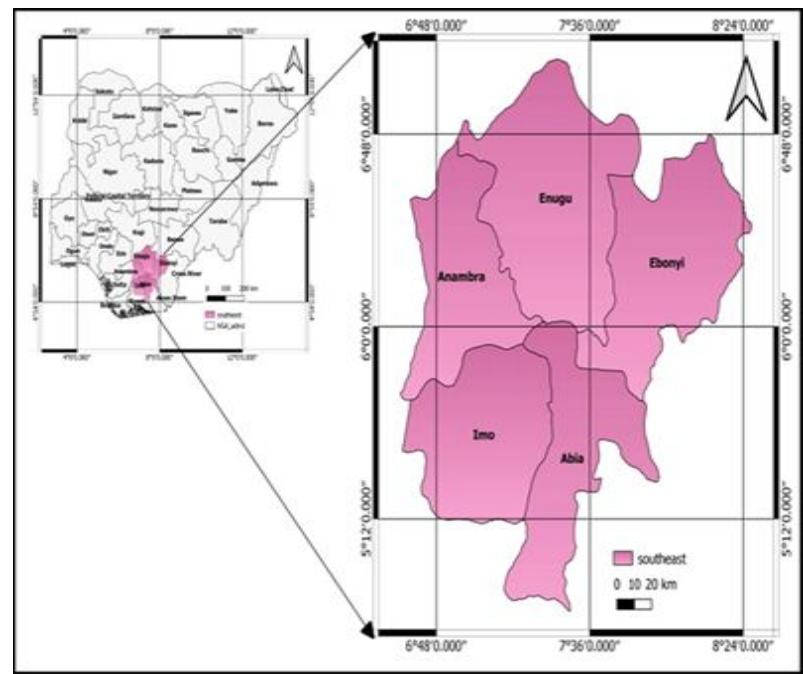

Fig. 1: Map of the study area (South East, Nigeria) Source: Source: Author's GIS Lab, 2020

\section{B. Pilot test}

This study conducted a pilot test on the validity and reliability of this study because of its use of questionnaire as the research instrument. Ascertaining both the validity and the reliability of the instrument to ensure that it measured the concept they were designed to measure is a necessity in research (Hair et al., 2010). Facial validation could be done as a crucial procedure in validating research instruments. The pilot study was conducted prior to the main data collection of this study. The essence of this was to get relevant feedback to improve the data collection process and the instrument used in the main study. In ensuring that the items of the questionnaire were properly adapted, this study conducted a content and construct test for the validation of the measuring instrument used in this research. The essence of this validity is to know whether meaningful inferences would be drawn from the measure of the instrument of this study by conducting a face validity test on the wordings and sequence of the items to determine which best suites the respondents among the alternative formats, to ascertain whether the items of this study would adequately measure the hypothetical concepts of the study (Creswell, 2009; Sekaran \& Bougie, 2009), and to foresee any challenges that might occur during the main data collection period and to prepare a back-up plan that would cater for any challenges that might arise during the main collection of data.

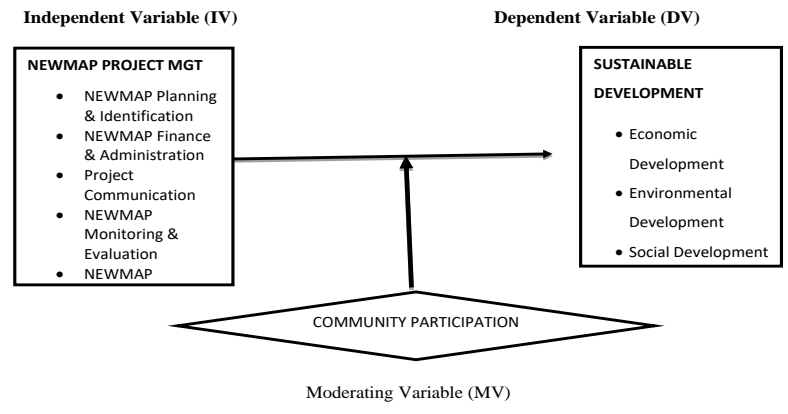

Fig. 2: Conceptual framework

Source: Creswell (2009)

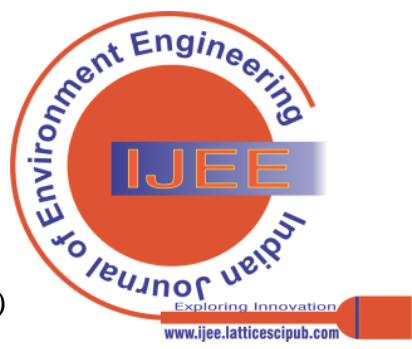


The facial validation was done by subjecting the questionnaire of this study to an in-depth review by academia and community development project practitioners. This was followed by making necessary corrections based on the comments received from reviewers. The validation process involved six (6) reviewers, four (4) of which are academicians while two (2) are practitioners. The comments received from these experts were implemented in the final research instrument used in collecting data for the main study. Basically, issues of double barrel questions, vague questions, and misrepresentation of ideas were all identified and corrected appropriately.

Upon the completion of the experts review of the instrument of this study, further test known as the reliability test was conducted to determine the internal consistency of the research instrument. Hair et al. (2010) assert that thirty (30) or more respondents are adequate for the conduct of pilot testing. Therefore, this study used 30 respondents for the purpose of the pilot study. The pilot sample was collected from Akwa Ibom state, in Nigeria. This is so because Akwa South-eastern states and has also piloted NEWMAP outside the South-east. The result of the pilot study in this research is interpreted by using Cronbach's Alpha value summarized in Table 1 . The result of the pilot test analysis indicates that the Cronbach's Alpha of the variables ranges from 0.832 to 0.964. Hair et al., (2010) assert that Cronbach's Alpha greater than 0.7 is accepted; however, value greater than 0.8 is preferable.

Table 1: Pilot Test Result

\begin{tabular}{|l|l|l|}
\hline Constructs & $\begin{array}{l}\text { Number } \\
\text { of items }\end{array}$ & $\begin{array}{l}\text { Cronbach's } \\
\text { Alpha }\end{array}$ \\
\hline $\begin{array}{l}\text { Economic Development } \\
\text { (ED) }\end{array}$ & 6 & 0.964 \\
\hline Social Development (SD) & 10 & 0.832 \\
\hline $\begin{array}{l}\text { Environmental Development } \\
\text { (EVD) }\end{array}$ & 5 & 0.872 \\
\hline $\begin{array}{l}\text { NEWMAP Planning and } \\
\text { Identification (NPPI) }\end{array}$ & 7 & 0.873 \\
\hline $\begin{array}{l}\text { NEWMAP Administration } \\
\text { (NPA) }\end{array}$ & 7 & 0.894 \\
\hline $\begin{array}{l}\text { NEWMAP Communication } \\
\text { (NPC) }\end{array}$ & 6 & 0.944 \\
\hline $\begin{array}{l}\text { NEWMAP } \\
\text { Implementation/Execution } \\
\text { (NPIE) }\end{array}$ & 5 & 0.881 \\
\hline $\begin{array}{l}\text { NEWMAP Monitoring and } \\
\text { Evaluation (NPME) }\end{array}$ & 6 & 0.943 \\
\hline $\begin{array}{l}\text { Community Participation } \\
\text { (CP) }\end{array}$ & 16 & 0.848 \\
\hline
\end{tabular}

Source: Hair et al.(2013)

This result shows that the values of the Cronbach's Alpha are all greater than 0.8 indicating a very good reliability of the research instrument. Therefore, none of the items were dropped from this study. Hence, the study questionnaire is deemed fit for use in the data collection of this study. Path analysis and multiple regression were used to investigate the NEWMAP on environmental development over South-East, Nigeria. Ibom state is one of the states that share similarities with the

\section{Inferential Statistics}

The Partial Least Square Structural Equation Modelling (PLS-SEM) would be used for the inferential statistics. Partial Least Square (PLS) is a second-generation multivariate analysis technique that combines the features of the first generation (principal components and linear regression analysis) (Fornell, 1982). This technique appropriately functions with structural equation models that have latent variables and series of cause-and-effect relationship (Hair et al., 2013). PLS-SEM provides researchers an opportunity to explore relationships among variables and identify the existing pathways among the variables (Hair et al., 2013). As such, it is regarded by Ringle, Wende and Will (2012) as an appropriate tool for building statistical model as well as prediction. This study specifically employed the use of PLS-SEM because of the following reasons:

Firstly, researchers have shown that PLS-SEM works efficiently by placing a minimum requirement on sample size to achieve adequate statistical power (Chin, 1998; Hair et al., 2013). PLS is advantageous to researchers due to its robustness of estimations and statistical power (Reinartz et al., 2009), which means that it is capable of rendering a specific relationship significant when it is indeed significant (Hair et al., 2013). It is indicated by Reinartz et al., (2009) that the sample size required by PLS-SEM is smaller compared to the other analytical tools. Following the rule of thumb in the application of PLS-SEM which states that the sample size should be 10 times the largest number of the structural paths directed at a construct in a structural model (Chin, 1998). This study considers the use of PLS-SEM as an appropriate tool.

Secondly, PLS path modelling has the ability to handle complex models with many structural model relations which makes it more appropriate to be applied in a real-life phenomenon (Hair et al., 2013). The soft modeling assumptions of PLS technique provides it with a greater ability to flexibly develop and validate larger complex models (Akter \& Hani, 2011). Hair et al., (2013) asserted that PLS-SEM is without competition in a situation that involves several path models with latent variables and complex structural relationships. This study involved nine path models within the structural model, and thus using PLS-SEM technique is appropriate for better validation.

Thirdly, one of the issues in social science researches is data non-normality (Mutum, 2011), and the statistical properties of PLS-SEM provides a very robust estimation with data that have normal and extremely distributional properties (i.e skewness and Kurtosis) (Reinartz et al., 2009; Ringle et al., 2009). Non-normal data are relatively treated well in PLS, thus the usage of PLS in this study is appropriate to help in treating issues related to non-normality of data during the analysis.

Fourthly, the use of PLS-SEM has been demonstrated by past researchers as having an ability to test moderation effect (Kadir, Said \& Singh, 2012). The result of PLS are more meaningful and valid while the conclusion of the results of the other analytical method are less clear which requires several other separate methods of analysis.

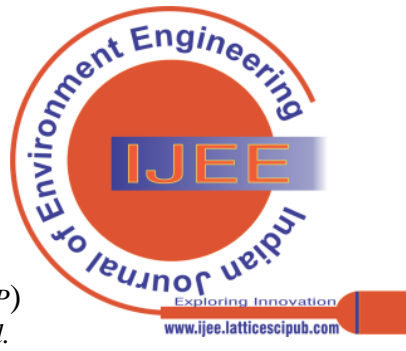


In order to understand the complex relationship associated with social science research, the use of PLS-SEM is necessary in the application of more sophisticated multivariate data analysis method (Hair et al., 2013). As such, it is regarded as a powerful tool with the ability to simultaneously test several relationships. This study employed smartPLS path modelling in establishing the measurement and the structural models. The measurement model provided an explanation on the assessment of the reliability and the validity of the constructs of the study, while the structural model was used to establish the correlation and the relationship effect among the construct's regression analysis. In addition, using the bootstrapping and PLS algorithm helped in analysing the hypotheses of this study and the moderating effects of community participation on the relationship between gully erosion occurrence and socio-economic implications.

\section{Formation of Research Hypotheses}

Five sub-hypotheses were developed for economic development as follows:

$\mathrm{H}_{1 \mathrm{a}}$ : NEWMAP planning and identification does not have a significant effect on economic development of South-east Nigeria.

$\mathrm{H}_{1 \mathrm{~b}}$ : NEWMAP Administration does not have a significant effect on economic development of South-east Nigeria.

$\mathrm{H}_{1 \mathrm{c}}$ : NEWMAP communication does not have a significant effect on economic development of South-east Nigeria.

H1d: NEWMAP implementation does not have a significant effect on economicdevelopment of South-east Nigeria.

H1e:NEWMAP monitoring and evaluation does not have a significant effect on economic development of South-east Nigeria.

Five sub-hypotheses were developed for social development as follows:

$\mathrm{H}_{2 \mathrm{a}}$ : NEWMAP planning and identification does not have a significant effect on social development of South-east Nigeria.

$\mathrm{H}_{2 \mathrm{~b}}$ : NEWMAP Finance and Administration does not have a significant effect on social development of South-east Nigeria.

$\mathrm{H}_{2 \mathrm{c}}$ : NEWMAP communication does not have a significant effect on social development of South-east Nigeria.

H2d: NEWMAP monitoring and evaluation does not have a significant effect on social development of South-east Nigeria.

H2e:NEWMAP implementation does not have a significant effect on social development of South-east Nigeria.

\section{RESULT AND DISCUSSION}

\section{A. Effect of NEWMAP project on economic development}

The result of the test of hypotheses 1 in this study as revealed in Table 2 shows the result of the standard path coefficients $(\beta)$, standard error, t-value and the decision in this study. The result indicated that three (3) among the five hypothesized relationships effect on NEWMAP demonstrated evidences of significant effect on economic development of South-east, Nigeria. The three (3) significant relationship include: (1) NEWMAP administration (NPA) and Economic development (ED) $(\beta=0.2083 ; \mathrm{t}=2.9145, \mathrm{P}<0.05)$; $(2)$ NEWMAP communication (NPC) and Economic development $(\mathrm{ED})(\beta=0.2647 ; \mathrm{t}=4.3362 ; \mathrm{P}<0.05)$; and 3$)$. NEWMAP Monitoring and Evaluation (NPME) and economic development (ED) $(\beta=0.1718 ; \mathrm{t}=1.9984 ; \mathrm{P}<$ 0.05 ) while the remaining path between NEWMAP planning and identification (NPPI) and economic development y (ED) $(\beta=0.0061 ; \mathrm{t}=0.0817 ; \mathrm{P}>0.05)$ and NEWMAP implementation (NPIE) and economic sustainability (ES) $(\beta=$ -0.0695; $\mathrm{t}=0.9253 ; \mathrm{P}>0.05$ ) did not demonstrate evidence of significant effects. Hence, hypotheses H1b, H1c, H1e are reject and the alternatives accepted while H1a and H1d are accepted.

This result indicates that NEWMAP administration, communication and monitoring and evaluation have significant effects on economic development while, NEWMAP implementation and planning and identification do not have significant effects on economic development of South-east Nigeria. The finding also shows that NEWMAP implementation and execution is negatively related to economic development. One plausible reason for this finding is because NEWMAP project is capital intensive and which might not pay-off in a short run.

This finding is in-line with Subbarano and Llyod (2011) and Bayer et al., (2013) who asserted that community development projects influences per capita income and employment generation of host communities. Even though, Subbrrano and Llyod (2011); Bayer et al., (2013) did not explicitly state the effect of the phases of development project on economic development of host communities. Also, the finding is similar to the result of Mori-Clement (2018) who found the impact of CDM projects as significant in improving the sustainable development of Brazilians. Specifically, Mori-Clement (2018) identified that community development mechanism projects significantly improve the living standards of the communities across Brazilian municipalities.

Furthermore, the finding of this study corroborates the assertion of Onder and Ulasan (2016) who found that administration of public development projects impacts economic development in South Korea. The success of economic growth development of communities is largely influenced multiple factors among which is administration of public infrastructure projects Accordinng to Onder and Ulasan (2016), the achievement of economic development characterized by rapid increase in gross domestic product, trade growth and per capita income of South Korea communities is owned to the proper administration of developmental project. In addition, Gannt (2006) also affirmed in his concept of development administration that proper administration of infrastructure projects/programmes creates hopes of higher national per capital income, a rapid rise in standards of living and increase in individual opportunities.

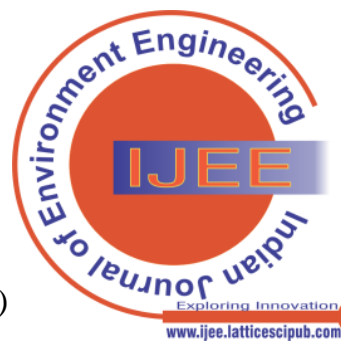


Similar to the findings above, the findings of this study on the effect of NEWMAP communication on economic development of South-east, Nigeria has revealed a positive effect of NEWMAP communication on economic development of south-east, Nigeria. This result implies that an increase in NEWMAP communication to the relevant stakeholders will improve the economic development of the communities. This result corroborates the findings of Berkett, Challenger, Sinnner, and Tadaki (2013) who regards communication of knowledge and information to those stakeholders involved in the developmental project as vital to achieving economic development. Hence, negotiation instead of directives in regards to NEWMAP has turn out to be an alternative mechanism to which developmental project can solve the complexity issues of the host communities.

Furthermore, the result of the effect of NEWMAP monitoring and evaluation on economic development in this study has revealed a positive significant influence on economic development of south-east, Nigeria as indicated in Table 2. The result implies that an increase in monitoring and evaluation of NEWMAP will improve economic development of south-east, Nigeria. This result supports the assertion of Adams (2016) on the importance of monitoring and evaluation of projects (M\&E) on economic development as critical to building a strong, global evidence-base reporting that enhances the assessment of the wide and diverse range of intervention projects to address economic challenges of the host communities. Also, it helps to track the effectiveness of the intervention projects (Table 2). Also, established that effective monitoring and evaluation of developmental project has been significant in the local economic development outcome in South-Africa. A proper monitoring and evaluation of fund projects in Kajiado East Sub-county of Kenya has improved the economic development of the constituency. Proper monitoring and evaluation of developmental project does not only significantly influence economic development of the host communities, it also enhances the development of economic policy that will enhance the optimal utilization of available resources that spurs investments for inclusive long-term and growth of economic development.

However, this result revealed an insignificant influence of NEWMAP planning and identification and NEWMAP implementation/execution on economic development of south-east, Nigeria (Table 2). This finding contradicts the findings of Onder and Ulasan (2016); Berkett et al., (2013) who identified planning and identification as the economic stimulus of economic development in host communities. One plausible explanation for the insignificant influence of NEWMAP planning and identification could be attributed to the lack of early identification of NEWMAP project and lack of contingent plan for slack time in the project.

Table 2: Effect of NEWMAP of Economic Development

\begin{tabular}{|c|c|c|c|c|l|}
\hline Hypotheses & Path Relationship & $\begin{array}{c}\text { Beta } \\
(\boldsymbol{\beta})\end{array}$ & T Statistics & $\begin{array}{c}\mathbf{P} \\
\text { Values }\end{array}$ & Decision \\
\hline $\mathbf{H}_{\mathbf{1}}$ & NPP1 -> ED & 0.0061 & 0.0817 & 0.9349 & Not-Significant \\
\hline $\mathbf{H}_{\mathbf{1 b}}$ & NPA -> ED & 0.2083 & 2.9145 & 0.0036 & Significant \\
\hline $\mathbf{H}_{\mathbf{1}}$ & NPC -> ED & 0.2647 & 4.3362 & 0.000 & Significant \\
\hline $\mathbf{H}_{\mathbf{1 d}}$ & NPIE -> ED & -0.0695 & 0.9253 & 0.3548 & Not-Significant \\
\hline $\mathbf{H}_{\mathbf{1}}$ & NPME -> ED & 0.1718 & 1.9984 & 0.0457 & Significant \\
\hline
\end{tabular}

Source: Field survey, 2020

Table 3: Effect of NEWMAP on social development

\begin{tabular}{cccccl}
\hline Hypotheses & Path Relationship & Beta $(\beta)$ & T Statistics & P Values & Decision \\
\hline $\mathrm{H}_{2 \mathrm{a}}$ & $\mathrm{NPA}->\mathrm{SD}$ & 0.265 & 2.493 & 0.013 & Significant \\
$\mathrm{H}_{2 \mathrm{~b}}$ & $\mathrm{NPC}->\mathrm{SD}$ & 0.243 & 2.145 & $\mathbf{0 . 0 3 2}$ & Significant \\
$\mathrm{H}_{2 \mathrm{c}}$ & $\mathrm{NPIE}->\mathrm{SD}$ & 0.225 & 2.9086 & $\mathbf{0 . 0 0 3 6}$ & Significant \\
$\mathrm{H}_{2 \mathrm{~d}}$ & $\mathrm{NPME}->\mathrm{SD}$ & 0.1001 & 1.0868 & 0.2772 & Not-Sign. \\
$\mathrm{H}_{2 e}$ & $\mathrm{NPP1}->\mathrm{SD}$ & 0.1581 & 2.26 & $\mathbf{0 . 0 2 3 9}$ & Significant \\
\hline
\end{tabular}

Source: Field survey, 2020

The result of the test of hypotheses 2 in this study as revealed in Table 2 shows the result of the standard path coefficients $(\beta)$, standard error, t-value and the decision in this study. The result indicated that four (4) among the five hypothesized relationships effect on NEWMAP demonstrated evidences of significant effect on social development of south-east, Nigeria. The four (4) significant relationship include: (1) NEWMAP administration (NPA) and social development (SD) $(\beta=0.265 ; \mathrm{t}=2.493, \mathrm{P}<0.05)$; $(2)$ NEWMAP communication (NPC) and social development y (SD) $(\beta=0.243 ; \mathrm{t}=2.145 ; \mathrm{P}<0.05) ; 3)$. NEWMAP implementation and Execution (NPIE) and social development $(\mathrm{SD})(\beta=0.225 ; \mathrm{t}=2.9086 ; \mathrm{P}<0.05)$; and
NEWMAP planning and Identification (NPPI) and Social sustainability $(\mathrm{SD})(\beta=0.1581 ; \mathrm{t}=2.26 ; \mathrm{P}<0.05)$. However, the relationship between NEWMAP monitoring and evaluation (NPME) and social development (SD) did not show an evidence of significant effect $(\beta=0.1001 ; \mathrm{t}=1.0868$; $\mathrm{P}>0.05$ ) (Table 3). Hence, hypotheses $\mathrm{H}_{2 \mathrm{a}}, \mathrm{H}_{2 \mathrm{~b}}, \mathrm{H}_{2 \mathrm{c}}$, and $\mathrm{H}_{2 \mathrm{e}}$ are rejected and their alternatives accepted while hypotheses $\mathrm{H}_{2 \mathrm{~d}}$ is accepted. This finding indicates that NEWMAP project administration, communication, implementation/execution, and planning and identification influences the social development of the south-east, Nigeria. However, monitoring and evaluation of NEWMAP does not influence the social development of the region. This findings imply that an increase in NEWMAP planning, administration, communication and implementation will improve social development of the South-east, Nigeria.

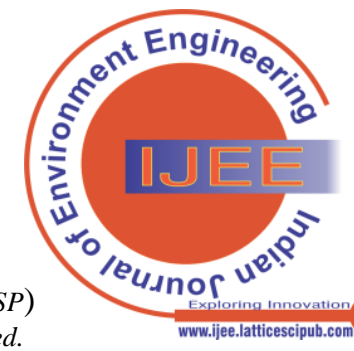


The result of this study is in-line with the findings of Owolabi, Okunlola and Mafimisebi (2018) who found that development project such as NEWMAP have significantly influenced the social development of the beneficiary communities. Specifically, this study found that NEWMAP planning and identification has a significant positive effect on the social development of South-east, Nigeria. The result of the beta value shows that there is a significantly weak relationship between NEWMAP planning and identification and social development. This finding corroborates the assertion of Halliday and Adebambo (2019) who argued that the using appropriate project management approach in exhibiting developmental project of this nature will positively enhance achievement of social development of communities that implement them. Also, the study corroborates the findings of Halliday and Adebambo (2019) who identified strategic planning of projects as a key factor that benefits the intended beneficiaries of HIV/AIDS project implementation in Abuja, Nigeria.

Furthermore, the findings of this study revealed a significant effect of NEWMAP project administration on sustainable development of South-east, Nigeria (Table 3). The finding indicates that an increase in the administration of NEWMAP significantly improves the social development of the South-east, Nigeria. The finding is similar to the assertion of Duke and Etim (2019) that administration of development project is aimed at stimulating social development in less developed/developing countries. Administration of project is an action that is deliberated to changing thins for good. It fosters social changes within a short period of time. Social development in the third world countries is a low standard of living and this can be improved when development projects are administered properly to alleviate the standard of living.

In addition, the finding of the study revealed a significant effect of NEWMAP project communication on the social development of South-east, Nigeria. The implication of the study is that an increase in the communication of NEWMAP project with the relevant stakeholders will positively improve social development of the south-east communities in Nigeria. This findings is similar to Lucas and Targema (2015) who found participatory communication as an important key to poverty alleviation projects in their investigation of the involvement of beneficiaries in poverty alleviation projects in Taraba state, Nigeria. The finding also corroborates the result of Adedokun, Adeyemo, and Olorunsola (2010) that effective communication strategy helps development projects beneficiaries to take ownership of the projects rather than seeing themselves as mere beneficiaries and hence, enhances their social development.

Furthermore, the findings of this study revealed a significant effect of NEWMAP implementation/execution on social development of South-east, Nigeria. This result implies that an increase in implementation of NEWMAP will improve the social development of the South-East, Nigeria (Table 3). Similar to the above relationships, this result corroborates the findings Owolabi et al., (2018). Owolabi et al., (2018) found Jalingo area of Taraba state in Nigeria has contributed significantly to the social development of the host communities. Also, Owolabi et al (2018) found a significant that the implementation of poverty alleviation projects in the

difference between the social development of communities that implemented developmental projects and those that did not implement in Ondo and Kwara state of Nigeria. Owolabi et al., (2018) identified the implementation of community and social developmental project as the drive behind social integration in Bayelsa, Nigeria.

The findings of the study found a significant effect of NEWMAP planning and identification on social development of South-east, Nigeria. The result implies that an increase in the planning and identification of NEWMAP will improve the social development of the South-east, Nigeria. This finding corroborates the assertion of Bappi, Singh and Dahiru (2018) who recommends the involvement of the rural communities' members in the identification and planning of their own beneficiaries' projects. It further states that encouragement should be made to create enabling environment where the people at the grass-root will participate actively in decision-making process that affect their condition of living and by so doing, it could stimulate the synergy between government and Community people as partners in progress and hence enhance social development (Bappi et al., 2018).

However, the finding of this study revealed an insignificant influence of NEWMAP monitoring and evaluation on social development of the South-east, Nigeria. This finding contradicts the result of Govender (2017); Yussuf et al., (2017) and Mugo (2014) who asserted that proper monitoring and evaluation of projects influences the sustainable development of the host communities. One plausible explanation for this insignificant influence of NEWMAP on social development of South-east, Nigeria may be owned to the inability of a regular meeting to monitor projects and NEWMAP progress being regularly compared with the project schedule which is rated neutral by the responses in the description of the NEWMAP monitoring and evaluation. One way to manage and review the progress of any project is by conducting and managing project progress which is achieved through team members and client meeting in which various status reports are created and shared with stakeholders as well.

\section{CONCLUSION}

The devastating effect of gully erosion has been more threatening in many parts of Nigeria, especially the south-east. Obviously, it has affected the economic, social and environmental development of the region. NEWMAP was developed to rehabilitate the degraded lands and reduce the erosion and climate vulnerability in targeted areas with potential effect of fostering sustainable development of the affected region in the form of positive economic, environmental and social development. The study posited that NEWMAP has the tendency of influencing the economic, social and environmental development of the host communities. From this, 30 hypotheses (both the direct and moderating hypotheses) were developed to represent the construct dimensional relationships.

Published By:

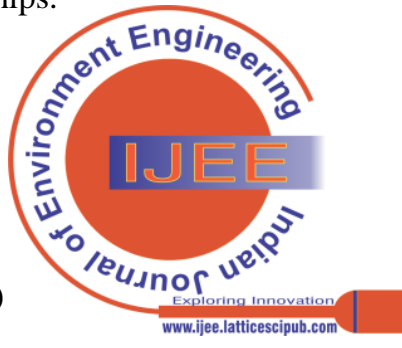


The result of the analysis found that 16 hypotheses including direct and moderating hypotheses were supported. Precisely, three among the direct hypotheses were supported to influence economic development of the south-east, Nigeria.

These include: NEWMAP project administration, NEWMAP communication and NEWMAP monitoring and evaluation. The study also found support for the influence of NEWMAP project planning and identification, NEWMAP administration, NEWMAP implementation and execution and NEWMAP communication on social development of the south-east, Nigeria. The influence of NEWMAP planning and identification, NEWMAP implementation and Execution; and NEWMAP monitoring and evaluation on the environmental development of south-east, Nigeria were supported.

\section{REFERENCES}

1. Adedokun, M.O, Adeyemo, C. W. and Olorusola, O. (2010). The impact of communication on community development: Journal of communication, 1, (1), 101-105. [CrossRef]

2. $\quad$ Akter, S. \& Hani, U. (2011). Complex modeling in marketing using component based SEM.Australian and New Zealand Marketing Academy Conference(ANZMAC2011), Perth, Western Australia: ANZMA, 1-9.

3. Bappi, U., Singh, D., and Dahiru, K. (2018). The effect of community participation on community development in Nigeria. International Journal of Advances in Arts, Science and Engineering, 6(13), 48 60 .

4. Bennett, J.; Crudgington, A. (2003), Sustainable development: recent thinking and practice in the UK. The Institution of Civil Engineers, 156, 27-32. [CrossRef]

5. Chin, W. W., (1998). The partial least squares approach to structural equation modeling. In: Marcoulides, G.A. (Ed.), Modern Methods for Business Research. Erlbaum, Mahwah, 295-358.

6. Climate Home News (2020). Erosion crisis swallows homes and livelihood in Nigeria. Retrieved online on 24/10/2020 fromwww.climatechangenews.com/2020/01/20/erosion-crisis-swallo ws -homes-livelihoods-Nigeria

7. Creswell, J. W. (2009). Research Design: qualitative, quantitative and mixed methods approaches $3^{\text {rd }}$ ed.). Los Angeles: Sage Publications Ltd.

8. Ezechi, J. I, \& Okagbue, C. O. (1989). A genetic classification of gullies in eastern Nigeria and its implications and control measures. Journal of African Earth Sciences (Middle East),9(3-4), 711-718. [CrossRef]

9. Ezezika O. \& Adetona, O. (2011). Resolving the gully erosion problem in Southeastern Nigeria: Innovation through public awareness and community-based approaches. Journal of Soil Science and Environmental Management, 2(10), 286-291.

10. Fornell, C., \& Larcker, D. F. (1981). Evaluating structural equation models with unobservable and measurement error. Journal of Marketing Research, 18, 39-50. [CrossRef]

11. Gannt, G. (2006). The concept of development administration. In , Otenyo, E.E. and Lind, N.S. (Ed.) Comparative Public Administration (Research in Public Policy Analysis and Management, Vol. 15), Emerald Group Publishing Limited, Bingley, pp. 257-285. [CrossRef]

12. Hair, J. F., Hult, G. T., Ringle, C. M. \& Sarstedt, M. (2013). A primer on partial least squares structural equation modeling (PLS-SEM). Sage Publications Ltd., Thousand Oaks, Carlifornia.

13. Halliday, S. (2008). Sustainable Construction. Stoneham, Mass: Butterworth-Heinemann. [CrossRef]

14. Henry, O., Alaga, A. T. and Ezekiel, E. O. (2016). An Assessment of Gully Erosion Progression and Vulnerability in Auchi Area in Edo State. Journal of Geography, Environment and Earth Science International, 7(2), 1 - 14. [CrossRef]

15. Kadir, R. A., Saaid, F. A. \& Singh, D. (2012). PLS path model for testing the moderating effects in the relationships among formative is usage variables of academic digital libraries. Australian Journal of Basic and Applied Sciences, 6(7), 365-374.

16. Mori-Clement, Y. (2018). Impacts of CDM projects on sustainable development: improving living standards across Brazilian municipalities? World Development, 113(2019), 222 - 236 [CrossRef]

17. Mutum, D. (2011). Non-normal data and SEM. Retrieved online on $4^{\text {th }} \quad$ August 2018 from: http://www.dilipmutum.com/2011/07/normality-issues-in-sem.html

18. Owolabi, K. E., Okunlola, J. O. and Mafimisebi, T. E. (2018) Influence of participation in community and social development projects on beneficiaries' income in Ondo and Kwara states, Nigeria. Int. J. Agr. Ext. 6(3). 2018. 203-214. [CrossRef]

19. NEMAP (2017). Nigerian Erosion and Watershed Management Project Akwa Ibom State ProjectManagement Unit.

20. NEWMAP (2018). Environmental and Social management Framework (ESMF) Final Report.

21. Onder, M. and Ulasan, F. (2016). The impact of public administration on economic growth: The case of South Korea. International Journal of Leadership and Management Studies, 1(1), 23 - 43.

22. Reinartz, W., Haenlein, M., Henseler, J., (2009). An empirical comparison of the efficacy of covariance-based and variance-based SEM. International Journal of Research in Marketing, 26(4), 332-344. [CrossRef]

23. Ringle, C. M., Wende, S., \& Will, A. (2005). SmartPLS 2.0. Retrieved from www.smartpls.de

24. Scheuer, W. (2007). Adoption of residential green building practices: understanding the role of familiarity, Unpublished Ph.D. Thesis, University of Michigan.

25. Sekaran, U. \& Bougie, R. (2009). Research methods for business: A skill building approach ( $5^{\text {th }}$ ed.). United Kingdom: John Wiley \& Sons Ltd.

26. Subbarao, S. \& Llyod, B. (2011). Can the clean development mechanism deliver ? Energy policy, 39(3), 1600 - 1611. [CrossRef]

27. Ujumadu, V., Okoli, A., Nkwopara, C., Igata, F., Nwaiwu, C., \& Ozor, C. (2016). Gully erosion: As rain begins, South-East communities already under threat. Accessed through vanguard Newspaper on $3^{\text {rd }}$ May, 2018

https:/www.vanguardngr.com/2016/03/

gullyerosion-as-rains-begin-south-eastcommunities-already-under -threat/

\section{AUTHORS PROFILE}

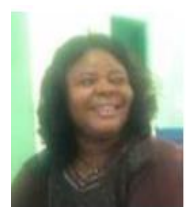

Oyati Edith Nwabuogo, is a COREN registered engineer and a Chief lecturer in the Department of Civil Engineering, Auchi Polytechnic, Auchi, Nigeria. She was formerly the Head of the Department of Civil Engineering and Dean School of Engineering Technology, Auchi Polytechnic, Auchi, Nigeria. She is currently a member of the Auchi Polytechnic Governing

Council.

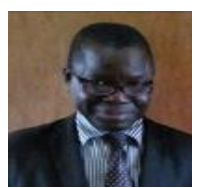

Akinloye Fatai Lawal, is a fellow of the Nigerian Institute of Building (NIOB). He is a professor of Construction Project Management with a specialization in energy management in buildings. He is currently the Dean, School of Management Technology, the Federal University of Technology in Akure, Nigeria.

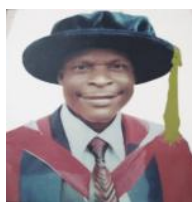

Oyewale Julius OJO, is current a lecturer in the Department of Project Management Technology, Akure, Nigeria. He is the Postgraduate Representative of the Department of Project Management Technology. He focuses on project planning, execution, and control.

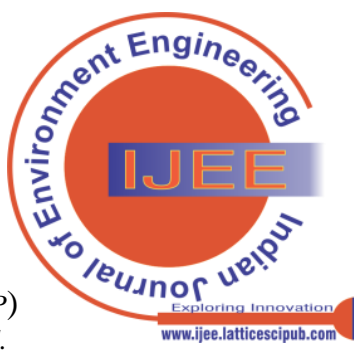

